\title{
Colostral Growth Factors
}

\section{Possible Role in Bovine Udder Epithelial Cell Regeneration}

\author{
By A. Iivanainen, E. Hölttä, A. Ståhls and L. C. Andersson \\ Department of Pathology, University of Helsinki and Department of Pharmacology and \\ Toxicology, College of Veterinary Medicine, Helsinki, Finland.
}

\begin{abstract}
livanainen A., E. Hölttä, A. Ståhls and L. C. Andersson: Colostral growth factors: Possible role in bovine udder epithelial cell regeneration. Acta vet. scand., 1992, 33, 197-203. - Growth of the secretory epithelium during prepartum time, and for a short period after calving, is under hormonal control by estrogen, progesterone and prolactin. The mechanism(s) by which these hormones act is not known but colostrum and milk have been shown to contain different growth promoting substances. In an attempt to unravel these relationships the effect of bovine colostrum on cellular proliferation in vitro have been characterized. Colostral thermostabile factors not present in milk nor associated with fat, potently induce the proliferation associated enzyme, ornithine decarboxylase, in fibroblast cell lines. However, mammary epithelial cells appear to proliferate in response to different colostral heat sensitive factor(s) that await further characterization.
\end{abstract}

colostrum; cell growth; ornithine decarboxylase.

\section{Introduction}

Stringent control of cell growth is the basis for all developing biology. This can be achieved by target cell specific expression of growth factor receptors. In addition, a complementary means of assuring specificity is to utilize an auto/paracrine production of growth factors or to actively recruite them locally and thus ensure their high concentration in the target tissues. Placental growth (Goustin et al. 1985), development of aortae in rat neonates (Ross et al. 1986), wound healing (Walker et al. 1986), liver regeneration (Mead \& Fausto 1989) and immune response (Smith 1990) are partly controlled by para/autocrine mechanisms.

Prepartum time and the immediate period after calving are characterized by dramatic, hormonally regulated changes in the secretory epithelium of the udder (Tucker 1985). Very little is known about the mechanism(s) by which the trophic effects are exerted. Colostrum, being produced during intensive cell proliferation contains different growth promoting substances. These include epidermal growth factor (EGF) (Carpenter 1980, Jaeger et al. 1987), insulin (Jaeger et al. 1987) and insulin-like growth factor 1 (IGF1) (Simmen et al. 1988). These small peptides or some other hitherto uncharacterized factors may act as mediators of the well documented hormonal effects in the mammary gland.

In initial pilot studies we found out that colo- 
strum supplementation is easily toxic for cultured cells, and difficulties were also encountered in the attempts to sterilize colostrum. These drawbacks could be overcome by screening colostral preparations based on their ability to induce cellular ornithine decarboxylase (ODC) in short term (few hours') cultures. ODC is the rate-limiting enzyme in the control of polyamine biosynthesis. Increased activity has been associated with cell proliferation in numerous studies reviewed by Jänne et al. 1978. In particular, ODC activity is elevated during regeneration of udder epithelium following clinical mastitis (Kaartinen et al. 1988).

We found that colostrum contains thermostabile factors not present in milk to which established fibroblast cell lines in vitro respond by induced ODC activity. Furthermore, with the help of ODC assay it is possible to prepare colostrum suitable for long term cultures in such a way that it retains its growth promoting activity. Experiments with primary cultures of the ductural udder epithelium suggest the presence of distinct thermolabile factor(s) that may contribute to regeneration of udder epithelium in vivo.

\section{Materials and methods}

Cells

MCF-7 mammary carcinoma cells (Michigan Cancer Foundation), NIH-3T3 fibroblasts trancfected with SV-40 NeoR (N1) or with MMTV-LTR neu -constructs (N6) were used (Lehväslaiho et al. 1989). For the establishement of bovine mammary epithelial cell (BMEC) cultures, epithelium from and proximal to sinus lactiferii was removed aseptically at slaugter. Cultures were established essentially as described by Sastrowidjojo \& Frost (1986). Cells were dispersed by trypsinization and agitation. After removal of cell clumps by passage through nylon wool columns, the cells were plated onto culture dishes in Dulbecco's Modified Eagles Medium (DMEM) + 10\% foetal calf serum (FCS) supplemented with antibiotics and antimycotics. Cells were maintained by passage 2 to 3 times a week in DMEM+10\% FCS with antibiotics. EGF was from Sigma (St. Louis, MO, USA).

\section{Preparation of colostrum}

Bovine colostrum was collected at the ambulatory clinic in Hautjärvi. The samples were frozen immediately at $-20^{\circ} \mathrm{C}$ until used. After thawing the colostrum was used as such or ultracentrifuged for $19 \mathrm{~h} \times 100000 \mathrm{~g}$ at $+2^{\circ} \mathrm{C}$. Clear infranatant (middle) layer was collected (called iCOL) and filtered. In some experiments $\mathrm{iCOL}$ was further boiled for 5 min, rapidly cooled and spinned for $15 \mathrm{~min} x$ $13000 \mathrm{~g}$ at $+4^{\circ} \mathrm{C}$. Clear supernatant was filtered and is termed bCOL.

\section{ODC assay}

Subconfluent cells were starved for $24 \mathrm{~h}$ in DMEM supplemented with $0.5 \%$ newborn calf serum (NBCS) or in serum-free DMEM. After stimulation (see Tables 1 and 2) for $6 \mathrm{~h}$ $10^{7}$ cells were harvested with a rubber policeman, collected and suspended in ice cold $25 \mathrm{mM}$ tris(hydroxymethyl)aminomethane hydrochloride (TRIS-HCl), $\mathrm{pH}=7.5 / 0.1 \mathrm{mM}$ ethylenediaminetetra-acetic cid (EDTA)/ $1 \mathrm{mM}$ dithiothreitol (DTT) and stored in $-70^{\circ} \mathrm{C}$ until measurement of enzymatic activity by the $\left[{ }^{14} \mathrm{C}\right] \mathrm{O}_{2}$-liberation method (Seely et al. 1982).

\section{$\left[{ }^{3} \mathrm{H}\right]$-thymidine $\left(\left[{ }^{3} \mathrm{H}\right]\right.$-dThd) incorporation}

Parallel cultures of BMEC were plated sparsely onto microtitre plates, cultivated in serum-free DMEM with the indicated supplements for 5 days and pulsed for the last 20 h with $1.0 \mu \mathrm{Ci}\left[{ }^{3} \mathrm{H}\right]$-dThd/well. Cells were 
harvested with semi-automatic cell harvester (Scatron, Norway) and the recovered radioactivity counted by liquid scintillation.

\section{Immunofluorescence staining}

BMEC were grown on coverslips, fixed with cold $\left(-20^{\circ} \mathrm{C}\right)$ methanol for $5 \mathrm{~min}$. After 2 washes in phosphate buffered saline (PBS) supplemented with $0.1 \%$ bovine serum albumin (BSA) coverslips were incubated for 30 min with or without $2 \mathrm{~A} 4$ anti-cytokeratine antibody (Virtanen et al. 1985) (1:20 in PBS $+10 \%$ FCS) and washed 3 times with PBS-BSA. The coverslips were further incubated with secondary antibody (fluorescein isothiocyanate -conjugated goat $\alpha$ mouse IgG, 1:30 in PBS-FCS) for $30 \mathrm{~min}$ in

Table 1. ODC-activity in starved N1(A)- or N6(B) -fibroblasts stimulated with colostrum, serum or EGF.

\begin{tabular}{lccc} 
A: N1 ODC-activity Relative activity & N \\
\hline kontr & $2007 \pm 462$ & 1,0 & 4 \\
dNBCS & $8200 \pm 3096$ & $4,3 \pm 2,1$ & 4 \\
iCOL & $10894 \pm 1211$ & $5,3 \pm 0,8$ & 4 \\
bCOL & $7003 \pm 1769$ & $3,6 \pm 1,6$ & 2 \\
EGF & 2940 & 1,23 & 1 \\
\hline
\end{tabular}

\begin{tabular}{|c|c|c|c|}
\hline B: N6 & ODC-activity & Relative activity & $\mathbf{N}$ \\
\hline kontr & $774 \pm 591$ & 1,0 & 2 \\
\hline dNBCS & $3950 \pm 71$ & $7,2 \pm 5,4$ & 2 \\
\hline $\mathrm{COL}$ & $4714 \pm 503$ & $4,0 \pm 0,5$ & 3 \\
\hline iCOL & $4619 \pm 503$ & $3,9 \pm 0,4$ & 3 \\
\hline $\mathrm{bCOL}$ & 3186 & 2,7 & 1 \\
\hline EGF & $686 \pm 212$ & $1,1 \pm 0,6$ & 2 \\
\hline
\end{tabular}

Starved cells $(24 \mathrm{~h}$ in DMEM $+0.5 \% \mathrm{NBCS})$ were stimulated for $6 \mathrm{~h}$ as indicated. ODC-activity is expressed as cpm $/ 10^{7}$ cells $/ 60 \mathrm{~min}$. Relative activity in unstimulated cells was set at 1.0. $\mathrm{ODC}=$ ornithine decarboxylase, dNBCS=dialyzed newborn calf serum, $\mathrm{COL}=$ colostrum, $\mathrm{iCOL}=$ infranatant colostrum from ultracentrifugation, $\mathrm{bCOL}=$ boiled colostrum, EGF=epidermal growth factor, DMEM=Dulbecco's Modified Eagles Medium. $\mathrm{N}=$ number of experiments.

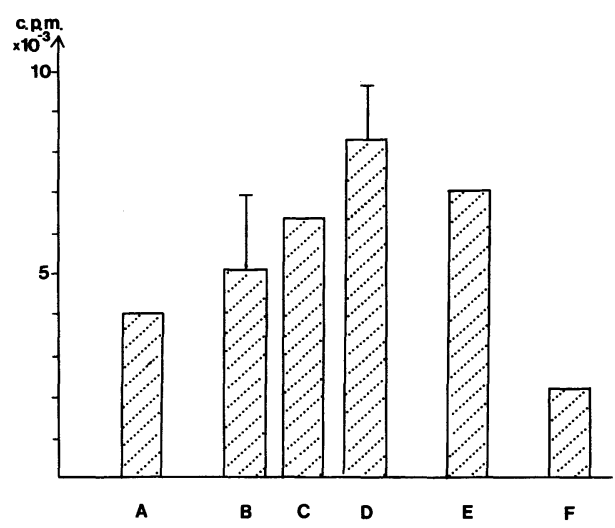

Figure 1. ODC-activity in neu-transfected NIH 3T3 fibroblasts stimulated for $6 \mathrm{~h}$ with $10 \%$ dNBCS (A), $2 \%$ (B), $5 \%$ (C), $10 \%$ (D) colostrum, $5 \%$ skimmed colostrum (E) or $10 \%$ milk (F). ODCactivity is expressed as cpm $/ 10^{7}$ cells $/ 60$ min. Activity in unstimulated control cells was $430 \mathrm{cpm}$. ODC=ornithine decarboxylase, $\mathrm{dNBCS}=$ dialyzed newborn calf serum.

dark followed by 3 additional washes. The slides were then mounted with PBS-glycerol $(1: 1)$.

\section{Results}

We found out that bovine colostrum is a very potent inductor of ODC in fibroblasts (Table 1). The activity was separable from fat since colostrum and ultrasentrifuged infranatant were equally potent. Because exogenous EGF did not stimulate ODC activity, colostral EGF is not sufficient for ODC-induction. The stimulating activity in colostrum was also partly resistant to heat. Boiling for 5 min precipitated around $60 \%-70 \%$ (vol $/ \mathrm{vol}$ ) of the sample. Heat-resistant supernatant (bCOL) was nearly as effective as unboiled colostrum in inducing ODC.

To examine the effect of colostral dose on ODC induction we used N6-cells transfected with neu -proto-oncogene (Lehväslaiho et al. 1989). Neu/c-erbB2 has been strongly impli- 


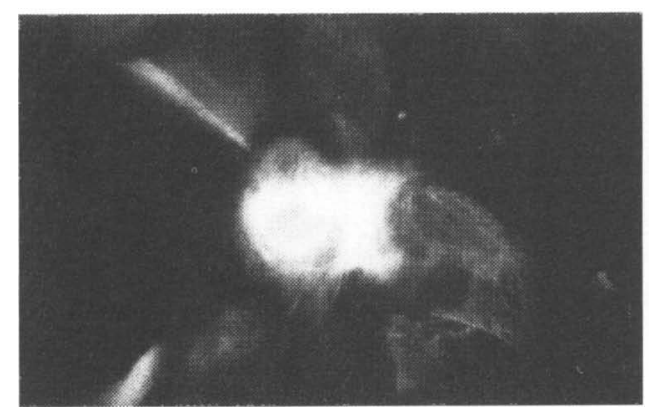

\begin{tabular}{lrr} 
Unstimulated & 9052 & 1,0 \\
FCS, $10 \%$ & 18650 & 2,0 \\
COL, $5 \%$ & 19412 & 2,1 \\
COL, $10 \%$ & 24660 & 2,7 \\
\hline
\end{tabular}

Starved cells ( $24 \mathrm{~h}$ in serum-free DMEM) were stimulated for $6 \mathrm{~h}$ as indicated. ODC-activity is expressed as $\mathrm{cpm} / 10^{7}$ cells $/ 60 \mathrm{~min}$. ODC=ornithine decarboxylase. $\mathrm{FCS}=$ foetal calf serum. $\mathrm{COL}=$ colostrum.

cated in malignant mammary growth (Muller et al. 1988, Slamon et al. 1987). From Fig. 1 it can be seen that the induction is dose dependent and that the inductor is not present in normal bovine milk and that it was not associated with fat. Another cell line, MCF-7, derived from mammary adenocarcinoma, responds very potently to colostrum as well (Table 2).

For the studies of the effect of colostrum in relevant cells, we established primary cultures of bovine mammary epithelium. The epithelial origin of these cultures was confirmed by demonstration of cytokeratin type intermediate filaments (Fig. 2). Colostrum stimulated DNA-synthesis in these cells very efficiently while EGF and bCOL were ineffective (Fig.3).

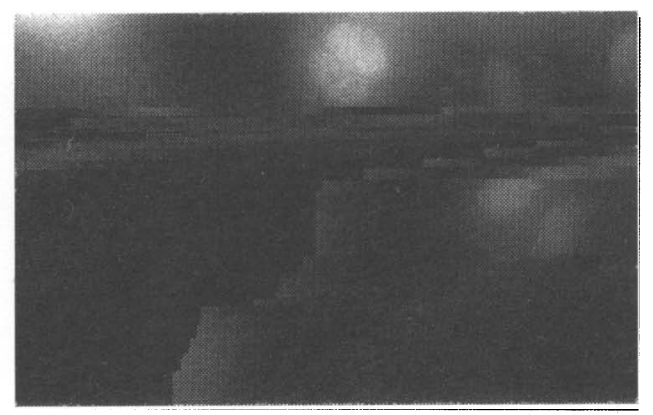

\section{Discussion}

Mammary secretions have been shown to contain many different growth factors (Carpenter 1980, Jaeger et al. 1987, Simmen et al. 1988, Tucker 1985). Of these EGF, in particular, has been considered to account for the majority of growth promoting activity in human milk (Carpenter 1980). We did not see EGF stimulation in our systems, however. This is hardly surprising in the case of 3T3-fibroblasts, which contain only about $10^{3}$ EGF-receptors per cell (Di Fiore et al. 1987). Unexpectedly, EGF did not promote udder epithelial cell growth either. Intactness of EGF was confirmed by its ability to induce ODC in cells known to express a high number of EGF-binding sites (not shown). Our findings do not exclude the functional significance of colostral EGF. Its physiological target could well be the offspring. EGF has been shown to play a part in cell proliferation in the gastrointestinal tract (WalkerSmith et al. 1985, Wright et al. 1990).

Other growth factors besides EGF in colostrum include insulin (Jaeger et al. 1987), IGF-1 (Simmen et al. 1988) and perhaps also serum derived peptides like platelet derived growth factor (PDGF). IGF-1 (Rinderknecht \& Humbel 1976) and PDGF (Antoniades et al. 1979) are resistant to heat. In contrast, the 


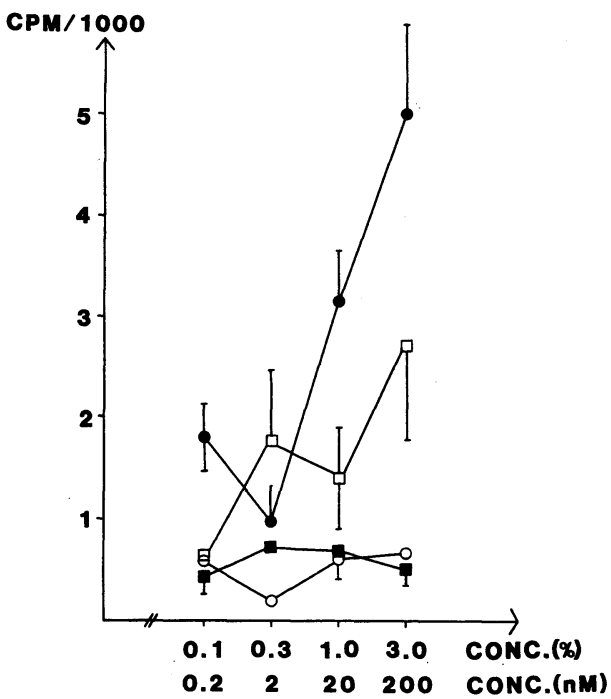

Figure 3. Colostrum but not EGF stimulated growth of bovine udder epithelial cells as measured by incorporation of exogenous $\left[{ }^{3} \mathrm{H}\right]$-thymidine. The concentration of EGF varies between 0.2 and 200 nM. The concentration of FCS and colostrum varies between 0.1 and $3 \%$ (vol/vol). ( $\square$ ) FCS, (O) ultracentrifuged colostrum, $(O)$ boiled colostrum and (घ) EGF. Note the logarithmic scale on the $x$-axis. EGF=epidermal growth factor, FCS=foetal calf serum, $\mathrm{CPM}=$ counts per $\min$, conc. $(\%)=$ concentration in units of $\%$, conc. $(\mathrm{nM})=$ concentration in units of nanomoles per litre.

stimulatory activity in colostrum which promotes mammary epithelial cell growth is totally distroyed by boiling (Fig. 3). To assess the role of insulin would require its removal or specific inactivation from colostrum. A possibility also remains for the presense of another (unidentified) factor that is not associated with fat (Fig. 3). Recent evidence on malignant growth of mammary epithelium suggests a role for EGFR-related receptors encoded by c-erb B2 (Muller et al. 1988, Slamon et al. 1987) and c-erb B3 (Kraus et al. 1989) proto-oncogenes. The products of both of these genes function very likely as growth factor regulated tyrosine kinases. This assumption is based on partial sequence identity to well characterized receptor tyrosine kinases (Hanks et al. 1988) and also to domain swapping experiments in which c-erb B2 -encoded kinase is brought under control of known hormones (Lee et al. 1989, Lehväslaiho et al. 1989). While the growth factors that activate these kinases are not yet characterized, their primary effect (as well as that of insulin) in the target cell is phosphorylation of cellular proteins on tyrosine residues (Ullrich \& Schlessinger 1990). Tyrosine specific phosphorylation is counteracted in the cell by phophotyrosine phosphatases (Tonks et al. 1989) which can be effectively and quite specifically blocked by sodium orthovanadate (Swarup et al. 1982). Interestingly, vanadate stimulates proliferation of bovine mammary epithelial cells in vitro (unpublished). This is compatible with the existence in these cells of cellular growth factor signal transduction system involving tyrosine phosphorylation.

\section{Acknowledgements}

We would like to thank Professor Ismo Virtanen, Department of Anatomy, University of Helsinki, for the kind gift of 2A4 antibody, Professor Kari Alitalo, Department of Pathology, University of Helsinki, for N1 and N6 cells, Ms. Anna Maria Siivonen, Mr. Matti Salonen and Ms. Anne Aronta for expert technical assistance, and Drs. Satu Pyörälä and Tiina Iivanainen, Ambulatory Clinic, Hautjärvi, for bovine colostrum.

This study was supported by Sigrid Juselius Foundation, The Academy of Finland, Magnus Ehnrooth's Foundation and Finnish Veterinary Science Foundation.

\section{References}

Antoniades $H N$, Scher $C D$, Stiles $C D$ : Purification of human platelet-derived growth factor. Proc. Natl. Acad. Sci. U.S.A. 1979, 76, 1809-1813.

Carpenter $G$ : Epidermal growth factor is a major growth-promoting agent in human milk. Science 1980, 210, 198-199. 
Di Fiore PP, Pierce JH, Fleming TP, Hazan R, Ullrich A, King CR, Schlessinger J, Aaronson SA: Overexpression of the human EGF receptor confers an EGF-dependent transformed phenotype to NIH-3T3 cells. Cell 1987, 51, 1063-1070.

Goustin AS, Besholtz C, Pfeifer-Ohlsson S, Persson $H$, Rydnert J, Bywater $M$, Holmgren $G$, Heldin $C-H$, Westermark $B$, Ohlsson $R$ : Coexpression of the sis and myc proto-oncogenes in developing human placenta suggests autocrine control of trophoblast growth. Cell 1985, 41, 301-312.

Hanks SK, Quinn AM, Hunter T: The protein kinase family: Conserved features and deduced phylogeny of the catalytic domains. Science $1988,241,42-52$.

Jaeger LA, Lamar CH, Bottoms GD, Cline TR: Growth stimulating substances in porcine milk. Amer. J. vet. Res. 1987, 48, 1531-1533.

Jänne J, Pösö H, Raina A: Polyamines in rapid growth and cancer. Biochem. Biophys. Acta 1978, 473, 241-293.

Kaartinen L, Veijalainen K, Kuosa PL, Pyörälä S, Sandholm M: Endotoxin- induced mastitis: Inhibition of casein synthesis and activation of the caseinolytic system. J. vet. Med. B 1988, 35, 353-360.

Kraus MH, Issing W, Miki T, Popescu NC, Aaronson $S A$ : Isolation and characterization of ERBB3, a third member of the ERBB/epidermal growth factor receptor family: Evidence for overexpression in a subset of human mammary tumors. Proc. Natl. Acad. Sci. U.S.A. 1989, 86, 9193-9197.

Lee J, Dull TJ, Lax I, Schlessinger J, Ullrich A.: HER2 cytoplasmic domain generates normal mitogenic and transforming signals in a chimeric receptor. EMBO J. 1989, 8, 167-173.

Lehväslaiho H, Lehtola L, Sistonen L, Alitalo K: A chimeric EGF-R -neu proto-oncogene allows EGF to regulate neu tyrosine kinase and cell transformation. EMBO J. 1989, 8, 159-166.

Mead JE, Fausto $N$ : Transforming growth factor $\alpha$ may be a physiological regulator of liver regeneration by means of an autocrine mechanism. Proc. Natl. Acad. Sci. U.S.A. 1989, 86, 15581562.

Muller WJ, Sinn E, Pattengale PK, Wallace R, Leder $P$ : Single-step induction of mammary adenocarcinoma in transgenic mice bearing the activated c-neu oncogene. Cell 1988, 54, 105-109.

Rinderknecht E, Humbel RE: Polypeptides with nonsuppressible insulin-like and cell-growth promoting activities in human serum: Isolation, chemical characterization, and some biological properties of forms I and II. Proc. Natl. Acad. Sci U.S.A. 1976, 73, 2365-2369.

Ross R, Raines EW, Bowen-Pope DF: The biology of platelet-derived growth factor. Cell 1986, 46, 155-169.

Sastrowidjojo S, Frost AJ: Cell cultures derived from bovine ductural epithelium for the investigation of mastitis. Austr. vet. J. 1986, 63, 194.

Seely JE, Pösö H, Pegg AE: Purification of ornithine decarboxylase from kidneys of androgen-treated mice. Biochemistry 1982, 21, 3394-3399.

Simmen FA, Simmen CM, Reinhart G: Maternal and neonatal somatomedin C/insulin-like growth factor -I (IGF-I) and IGF binding proteins during early lactation in the pig. Dev. Biol. 1988, 130, 16-27.

Slamon DJ, Clark GM, Wong SG, Levin WJ, Ullrich A, McGiure WL: Human breast cancer: Correlation of relapse and survival with amplification of the HER-2/neu oncogene. Science 1987, $325,177-182$.

Smith KA: Interleukin-2. Sci. Amer. 1990, 262, 2633.

Swarup G, Speeg KV Jr, Cohen S, Garbers DL: Phosphotyrosyl-protein phosphatase of TCRC2 cells. J. Biol. Chem. 1982, 257, 7298-7301.

Tonks NK, Charbonneau H, Diltz CD, Kumar S, Cicirelli MF, Krebs EG, Walsh KA, Fischer EH: Protein tyrosine phosphatases: structure, properties and role in signal transduction. Adv. Protein Phosphatases 1989, 5, 149-180.

Tucker HA: Endocrine and neural control of the mammary gland. In: Larson BL (ed.): Lactation, The Iowa State University Press, Ames, 1985. pp. 39-79.

Ullrich A, Schlessinger J: Signal transduction by receptors with tyrosine kinase activity. Cell 1990, 61, 203-212.

Virtanen I, Miettinen M, Lehto V-P, Kariniemi AL, Paasivuo $R$ : Diagnostic application of monoclonal antibodies to intermediate filaments. Ann. NY. Acad. Sciences 1985, 455, 635-648.

Walker LN, Bowen-Pope DF, Ross R, Reidy MA: Production of PDGF-like molecules by cultured arterial smooth muscle cells accompanies proliferation after arterial injury. Proc. Natl. Acad. Sci. U.S.A. 1986, 83, 7311-7315.

Walker-Smith JA, Phillips AD, Walford N, Gregory $H$, Fitzgerald JD, MacCullagh $K$, Wright $N A$ : Intravenous epidermal growth factor/urogastro- 
ne increases small intestinal cell proliferation in congenital microvillous atrophy. Lancet $1985, i i$, 1239-1240.

Wright NA, Pike C, Elia G: Induction of a novel epidermal growth factor -secreting cell lineage by mucosal ulceration in human gastrointestinal stem cells. Nature 1990, 343, 82-85.

\section{Sammandrag}

Tillväxtstimulerande faktorer $i$ kolostrum: möjlig roll $i$ epitelcellregenerationen $i$ kojuver.

Det sekretoriska epitelets tillväxt i juvret under prepartum och en kort period efter kalvinigen står under hormonal kontroll genom estrogen, progesteron och prolaktin. De mekanismer genom vilka dessa hormoner utövar sin verkan är ej kända, men kolostrum och mjölk har påvisats innehålla tillväxtstimulerande faktorer. I ett försök att komma till klarhet med dessa mekanismer har vi studerat effekten av kolosrum från ko på cellers tillväxt in vitro. Kolostrala värmestabila faktorer, ej närvarande i mjölk eller associerade med fett, inducerar i fibroblastcellinjer en kraftig ökning i aktiviteten av ornitindekarboxylas, som är ett tillväxtassocierat enzym. Men epiteliala celler i juvret verkar även känna igen andra, ännu inte karaktiserade faktorer i kolostrum.

(Received June 18, 1990; accepted September, 7, 1990).

Reprints may be requested from: Antti Iivanainen, Department of Pharmacology and Toxicology, College of Veterinary Medicine, Hämeentie 57, SF-00580 Helsinki, Finland. 